HW3-56

\title{
Progress in single junction microcrystalline silicon solar cells deposited by Hot-Wire CVD
}

M. Fonrodona, D. Soler, F. Villar, J. Escarré, J.M. Asensi, J. Bertomeu and J. Andreu

CeRMAE - Departament de Física Aplicada i Òptica, Universitat de Barcelona, Av. Diagonal 647, 08028 Barcelona, Spain .

\begin{abstract}
Hot-Wire Chemical Vapor Deposition has led to microcrystalline silicon solar cell efficiencies similar to those obtained with Plasma Enhanced CVD. The light-induced degradation behavior of microcrystalline silicon solar cells critically depends on the properties of their active layer. In the regime close to the transition to amorphous growth (around $60 \%$ of amorphous volume fraction), cells incorporating an intrinsic layer with slightly higher crystalline fraction and [220] preferential orientation are stable after more than 7000 hours of AM1.5 light soaking. On the contrary, solar cells whose intrinsic layer has a slightly lower crystalline fraction and random or [111] preferential orientation exhibit clear light-induced degradation effects. A revision of the efficiencies of Hot-Wire deposited microcrystalline silicon solar cells is presented and the potential efficiency of this technology is also evaluated.
\end{abstract}

\section{Keywords}

Microcrystalline silicon, Hot-Wire CVD, Solar Cells 


\section{Introduction}

Hot-Wire Chemical Vapor Deposition (HWCVD or Cat-CVD) has led to solar cell efficiencies similar to those obtained with Plasma Enhanced CVD (PECVD) [1]. The main advantages of HWCVD are higher deposition rates, suitability for scaling up in large area industrial applications, and absence of powder formation and ion bombardment.

Depending on the deposition sequence, two structures are considered: $p-i-n$ and n-i-p. The former is commonly used on transparent substrates, whereas n-i-p structures are usually deposited on opaque substrates. Transparent conductive oxide (TCO) is also a key material in these cell structures, as glass/TCO, stainless steel (SS) and SS/metal/TCO are the most usual substrates used. $\mu \mathrm{c}-\mathrm{Si}: \mathrm{H}$ is grown in atomic hydrogen rich atmospheres, what can cause the chemical reduction of the $\mathrm{TCO}[2]$. $\mathrm{ZnO}: \mathrm{Al}$ has turned out to be resistant to this reduction process.

A suitable surface roughness also contributes to enhance the optical absorption in the thin intrinsic layer, and commercial $\mathrm{SnO}_{2}$ (Asahi-U) covered with a thin $\mathrm{ZnO}$ :Al layer or textured $\mathrm{ZnO}: \mathrm{Al}$ have shown good results in $\mathrm{p}-\mathrm{i}-\mathrm{n}$ solar cells.

Despite the fact that a growing number of research groups are developing $\mathrm{p}-\mathrm{i}-\mathrm{n}$ or $\mathrm{n}-\mathrm{i}-\mathrm{p}$ $\mu \mathrm{c}-\mathrm{Si}: H$ solar cells fully deposited with HWCVD, the highest efficiencies up to now have been obtained using doped layers grown by PECVD [1].

Fig. 1 presents an overview of the evolution of the efficiency and the rest of the parameters obtained from the $\mathrm{J}(\mathrm{V})$ curve of $\mu \mathrm{c}-\mathrm{Si}: \mathrm{H}$ solar cells deposited by HWCVD, as a function of the year of publication of the result. The contributions included are from University of Barcelona [35], Forschungszentrum Jülich [1,6], University of Kaiserslautern [7], CNRS-École Polytechnique de Palaiseau [8,9], Utrecht University [10-12], Tokyo Institute of Technology [13,14] and National Renewable Energy Laboratory (NREL) [15].

$\mu \mathrm{c}-\mathrm{Si}: \mathrm{H}$ solar cells deposited with HWCVD have been developed during a much shorter period than that devoted to PECVD deposited ones. In spite of this fact, the efficiency of the best cells incorporating the intrinsic $\mu \mathrm{c}-\mathrm{Si}: \mathrm{H}$ layer deposited with HWCVD have reached 9.4\% efficiency [1], which is close to the record of $10.1 \%$ achieved in $\mu \mathrm{c}-\mathrm{Si}: \mathrm{H}$ solar cells deposited using plasma techniques [16]. Besides, devices having all the $\mu \mathrm{c}-\mathrm{Si}: \mathrm{H}$ layers deposited by HWCVD have led to efficiencies above 5\% [5,7,15]. 
In order to summarize the main aspects that influence the efficiency of solar cells deposited by HWCVD, two different approaches should be distinguished: the low substrate temperature approach $\left(\mathrm{T}_{\mathrm{s}} \leq 350^{\circ} \mathrm{C}\right)$ and the high temperature one $\left(\mathrm{T}_{\mathrm{s}}>350^{\circ} \mathrm{C}\right)$.

The high temperature regime avoids grain boundaries with high densities of hydrogen and, therefore, makes it easier to grow dense material. This regime allowed the deposition of dense material with [220] orientation [17]. Early cells deposited at high $T_{s}$ at Utrecht University [10] where stable but suffered from moderate open circuit voltage $\left(\mathrm{V}_{\mathrm{oc}}\right)$. Further developments in the same group led to higher $\mathrm{V}_{\mathrm{oc}}$ with high deposition rates $(1.3 \mathrm{~nm} / \mathrm{s})$ by lowering the wire temperature $\left(\mathrm{T}_{\mathrm{f}}\right)[12]$.

In first attempts, low temperature solar cells were unstable due to oxygen contamination of the porous silicon layers. Accurate selection of deposition parameters was, thus, necessary to grow dense $\mu \mathrm{c}-\mathrm{Si}: \mathrm{H}$ at low $\mathrm{T}_{\mathrm{s}}[18]$. The key parameters in the low $\mathrm{T}_{\mathrm{s}}$ approach are $\mathrm{T}_{\mathrm{f}}$, the silane concentration (SC), and the pressure (P). Device-quality $\mu \mathrm{c}-\mathrm{Si}: \mathrm{H}$ is obtained at $\mathrm{T}_{\mathrm{f}}$ between $1500^{\circ} \mathrm{C}$ and $1700^{\circ} \mathrm{C}$, SC between $3 \%$ and $15 \%$ in hydrogen and $\mathrm{P} \cdot \mathrm{d} \sim 10 \mathrm{~Pa} \cdot \mathrm{cm}$, where $\mathrm{d}$ is the distance between the filament and the substrate.

\section{Light induced degradation}

The effect of light-induced degradation in amorphous silicon (a-Si:H) has been the center of many studies. Even if there is some controversy on the detailed local sites and energies involved, it is a general agreement that such effect is caused by a change in the hydrogen bonding leading to a change in the density of dangling bonds [19]. On the contrary, light soaking experiments performed on n-i-p and p-i-n $\mu \mathrm{c}-\mathrm{Si}: \mathrm{H}$ solar cells with high crystalline volume fraction evidenced a stable behavior $[7,20]$.

Recent results regarding $\mu \mathrm{c}-\mathrm{Si}: \mathrm{H}$ solar cells have shown that best device performance is found using $\mu \mathrm{c}-\mathrm{Si}: \mathrm{H}$ obtained in a regime close to the transition to amorphous growth $[21,6]$. This kind of material has a significant amount of amorphous tissue which can turn out to enhance the degradation of the device when exposed to long time illumination due to the so-called StaeblerWronski effect [22] (SWE). The recombination properties of $\mu \mathrm{c}-\mathrm{Si}: \mathrm{H}$ are attributed to recombination in the dangling bond defects present in the amorphous phase among the 
crystallites. Light-induced degradation up to $10 \%$ of the initial cell efficiency has been reported in p-i-n cells with high amorphous fractions [6].

We present here the degradation effects imputable to (meta-stable) defect creation within the active layer of the $\mu \mathrm{c}-\mathrm{Si}: \mathrm{H}$ solar cells. Apart from these reversible instabilities, a $\mu \mathrm{c}-\mathrm{Si}: \mathrm{H}$ solar cell has a tendency to suffer from irreversible instabilities (mainly chemical). Fortunately, the analysis techniques used in this work allow the discrimination of the different degradation mechanisms, thus making it possible to concentrate our studies on those effects concerning the intrinsic layer of the device. The effective carrier mobility-lifetime product $\left(\mu \tau_{\text {eff }}\right)$ is a relevant magnitude in the characterization of the recombination process in p-i-n solar cells [23-25]. The Variable Illumination Measurement technique (VIM) allows the determination of the $\mu \tau_{\text {eff }}$ [26] from which the defect density within the active layer of the device can be evaluated.

p-i-n solar cells were completely deposited by HWCVD in a multichamber set-up [27] on $\mathrm{ZnO}$ :Al coated Asahi-U substrates. Structural differences in the microstructure of the active layer were achieved by changing SC, i.e. the percentage of silane in the total gas flow, close to the transition to amorphous growth. The rest of the deposition conditions were the ones leading to compact material at low tantalum wire temperature [18]. Several silane gas phase concentrations values were considered in this study, but only cells having the active layer deposited using $\mathrm{SC}=$ $6.2 \%$ and $5.6 \%$ are presented here in detail, as they had different behavior when long exposed to AM1.5 illumination. Devices deposited at lower SC exhibited the same behavior than that at $5.6 \%$, whereas those deposited using less hydrogen behaved like that grown at $\mathrm{SC}=6.2 \%$. The thickness of the active layer was $1 \mu \mathrm{m}$ in both cases. The microstructure of the cells was analyzed by Raman spectroscopy, from which the crystalline fraction was estimated, and Transmission Electron Microscopy (TEM). Stability of the devices during light soaking process was evaluated from the evolution of the $\mu \tau_{\text {eff }}$ obtained from VIM measurements [26].

Fig. 2 shows the evolution of $\mu \tau_{\text {eff }}$ with AM1.5 exposure for the two cells considered. Surprisingly, that deposited at $\mathrm{SC}=5.6 \%$ had a constant $\mu \tau_{\text {eff }}$ value around $8 \cdot 10^{-8} \mathrm{~cm}^{2} / \mathrm{V}$, which meant that no light-induced defects were created during almost 7000 hours of illumination. On the contrary, the $\mu \tau_{\text {eff }}$ value of the cell deposited using $\mathrm{SC}=6.2 \%$ decreased from $1.1 \cdot 10^{-7}$ to $3 \cdot 10^{-8} \mathrm{~cm}^{2} / \mathrm{V}$ (solid symbols) after 1000 hours of light soaking. This degradation was partially reversed after a thirty-minute annealing at $180^{\circ} \mathrm{C}\left(\mu \tau_{\text {eff }}=4.6 \cdot 10^{-8} \mathrm{~cm}^{2} / \mathrm{V}\right)$, evidencing the coexistence of two different degradation mechanisms: an irreversible one-imputable to chemical 
changes or doping diffusion- and a meta-stable one, associated to SWE-like light-induced defect creation. After the annealing, the sample was exposed to illumination again, and a second annealing took place after 6000 hours of illumination (open circles in Fig. 2), causing $\mu \tau_{\text {eff }}$ to return to a value of $4.1 \cdot 10^{-8} \mathrm{~cm}^{2} / \mathrm{V}$.

Raman measurements showed that both cells had a very similar amount of amorphous fraction. Raman spectra of the solar cells, as well as their difference can be seen in Fig. 3. Crystalline fractions calculated from these spectra resulted in a difference of around $5 \%$ (Xc 0.45 for $\mathrm{SC}=5.6 \%$ and $\mathrm{Xc} \sim 0.40$ for $\mathrm{SC}=6.2 \%$ ). Thus, it was very unlikely that such a small divergence could be the cause of a sharp edge regarding light-induced degradation.

TEM cross-section images allowed a more thorough study of the microstructure of the cells. A larger amount of grains was observable at $\mathrm{SC}=5.6 \%$, having a broader distribution of sizes from several nanometers to a few tens and closer to each other. The medium distance between grains was $3 \mathrm{~nm}$ in this case, whereas grains were an average of $10 \mathrm{~nm}$ apart in the cell deposited at $\mathrm{SC}=6.2 \%$.

The presence of the different possible crystalline orientations was seen from the Fast Fourier Transform (FFT) treatment of High-Resolution TEM (HRTEM) images at different depths of the active layer (close to the $\mathrm{p} / \mathrm{i}$ interface, in the middle of the $\mathrm{i}$-layer and close to the $\mathrm{i} / \mathrm{n}$ interface). As can be seen in Fig. 4, a significant difference between both samples was clearly observable. In the case of the cell deposited at $\mathrm{SC}=6.2 \%$, (111) crystalline orientation was seen throughout the whole layer, and (220) orientation was only very dimly observable close to the interface with the n-layer. Conversely, analyzing the images of the cell at SC $=5.6 \%$, even though only (111) was observed close to the $\mathrm{p} / \mathrm{i}$ interface -during the first growth stages of the i-layer-, (220) orientation was soon detected and became more intense as the $\mathrm{i} / \mathrm{n}$ interface was approached.

Analyzing the structural properties of the two p-i-n solar cells considered, and taking into account the similar amount of amorphous tissue measured in both cases, it seemed to point out that the orientation of the grains played a role regarding the stability of the material against light exposure. In special, $\mu \mathrm{c}-\mathrm{Si}: \mathrm{H}$ solar cells with preferential crystalline orientation in the (220) direction had a stable $\mu \tau_{\text {eff }}$ value -and, therefore, a stable defect density- after 7000 hours of AM1.5 light exposure. This result contrasted with those of the Jülich [1] and the Kaiserslautern group [7], where high efficiency and stability, respectively, were achieved incorporating $\mu \mathrm{c}-\mathrm{Si}: \mathrm{H}$ randomly orientated in their solar cells. 
On the other hand, cells with different crystallographic orientation presented clear lightinduced defect creation that was partially recovered after thermal annealing. As already mentioned, even if the stable cell had a slightly lower amount of amorphous volume fraction, it would be difficult to impute the different degradation behavior to this fact. One possible explanation could be that some change in the transport mechanism between the crystalline grains happened with the change in preferential orientation. Further experimental research is necessary to elucidate the physical origin of this surprisingly abrupt change in the light-induced degradation of $\mu \mathrm{c}-\mathrm{Si}: \mathrm{H}$ solar cells.

The stable solar cell presented here, that deposited at $\mathrm{SC}=5.6 \%$, had an efficiency of $5.2 \%$ $\left(\mathrm{J}_{\mathrm{sc}}=17.4 \mathrm{~mA} / \mathrm{cm}^{2}, \mathrm{~V}_{\mathrm{oc}}=0.47 \mathrm{~V}\right.$ and $\left.\mathrm{FF}=0.63\right)$. Fig. 5 presents the $\mathrm{J}(\mathrm{V})$ curve under AM1.5 $\left(100 \mathrm{~mW} / \mathrm{cm}^{2}\right)$ illumination (a) and the wavelength dependence of the external quantum efficiency (b). 5.2\% efficiency is, to our knowledge, the highest value reported for a completely Hot-Wire deposited microcrystalline silicon $\mathrm{p}-\mathrm{i}-\mathrm{n}$ solar cell. Higher efficiencies $[15,7]$ and enhanced stability [7] have been reported for fully Hot-Wire grown devices using the substrate (n-i-p) configuration.

\section{Efficiency limits of $\mu \mathrm{c-Si}: \mathrm{H}$ solar cells}

The efficiency of $\mu \mathrm{c}-\mathrm{Si}: \mathrm{H}$ solar cells is mainly limited by the low absorption in the thin intrinsic layer and by recombination. The optical absorption within the intrinsic layer can be enhanced using optical confinement strategies: best solar cells present a short circuit current of $25 \mathrm{~mA} / \mathrm{cm}^{2}$, and the theoretical limit is $40 \mathrm{~mA} / \mathrm{cm}^{2}$.

The short circuit current $\left(\mathrm{J}_{\mathrm{sc}}\right)$ equals the generation in the intrinsic zone minus the recombination. In short circuit conditions in good solar cells -those with low recombination-, $\mathrm{J}_{\mathrm{sc}}$ is close to the generation in the intrinsic layer. $\mathrm{V}_{\mathrm{oc}}$ and the fill factor $(\mathrm{FF})$ are strongly affected by both transport and recombination. A numerical simulation using the program and parameters for the dangling bond distribution described in [23] is presented in Table 1 for a $\mu \mathrm{c}-\mathrm{Si}: \mathrm{H}$ solar cell with a $1 \mu \mathrm{m}$-thick intrinsic layer, using different mobilities (same value for both holes and electrons was considered) and dangling bond density $\left(\mathrm{N}_{\mathrm{d}}\right)$ values. The integrated generation in the intrinsic layer considered in all cases was $25 \mathrm{~mA} / \mathrm{cm}^{2}$. 
It can be seen that the main parameter affecting the efficiency is the defect density. When $\mathrm{N}_{\mathrm{d}}$ is very high, the electric field is screened and the efficiency of the cell dramatically drops. Only in this case (high $\mathrm{N}_{\mathrm{d}}$ ), the efficiency of the solar cell significantly depends on the mobility of the carriers. These results strongly point out that low defect density material and improved optical confinement is necessary to increase the efficiency of $\mu \mathrm{c}-\mathrm{Si}: \mathrm{H}$ solar cells. These requirements are easier to achieve at low temperature. Minimization of the heat coming from the wire is necessary to increase the efficiency of $\mu \mathrm{c}-\mathrm{Si}: \mathrm{H}$ solar cells deposited with HWCVD.

\section{Conclusions}

The development of $\mu \mathrm{c}-\mathrm{Si}: \mathrm{H}$ solar cells deposited by HWCVD is leading to higher efficiencies year after year.

Preferential (220) crystalline orientation seemed to be required to avoid light induced degradation. After 1000 hours of light soaking, the FF was still degrading for the unstable cells, whereas the stable ones remained so after $7000 \mathrm{~h}$ of illumination.

Low temperature deposition and light confinement are the approaches that can probably lead to higher cell efficiencies in the near future.

\section{Acknowledgements}

This work has been financed by the CICYT of the Spanish Government (MAT2001-3541-C0301). The authors want to thank the Scientific-Technical Services of the UB for Raman and TEM measurements and Roger Buser for his work on the measurements set-up.

\section{References}

1. S. Klein, F. Finger, R. Carius, B. Rech, L. Houben, M. Luysberg, M. Stutzmann, Mat. Res. Soc. Symp. Proc. 715 (2002) A26.2.

2. T. Minami, H. Sato, H. Nanto, S. Takata, Thin Solid Films 176 (1989) 277. 
3. D. Peiró, J. Bertomeu, C. Voz, J.M. Asensi, J. Puigdollers, J. Andreu, in: H.S. Stephens \& Associates (Eds.) Proceedings of the 14th European Photovoltaic Solar Energy Conference, Barcelona, Spain, June 30 - July 4, 1997, p.1428.

4. C. Voz, D. Peiró, J. Bertomeu, D. Soler, M. Fonrodona, J. Andreu, Mater. Sci. Eng. B69-70 (2000) 278 .

5. M. Fonrodona, D. Soler, J. Escarré, J.M. Asensi, J. Bertomeu, J. Andreu, J. Non-Cryst. Solids 338-340 (2004) 659.

6. S. Klein, F. Finger, R. Carius, T. Dylla, B. Rech, M. Grimm, L. Houben and M. Stutzmann, Thin Solid Films 430 (2003) 202.

7. M. Kupich, D. Grunsky, P. Kumar, B. Schröeder, Sol. Energy Mater. Sol. Cells 81 (2004) 141.

8. C. Niikura, S.Y. Kim, B. Drevillon, Y. Poissant, P. Roca i Cabarrocas, J.E. Bouree, Thin Solid Films 395 (2001) 178.

9. C. Niikura, Y. Poissant, M.E. Gueunier, J.P. Kleider, J.E. Bouree, J. Non-Cryst. Solids 299$302(2002) 1179$.

10. J.K. Rath, H. Meiling, R.E.I. Schropp, Jpn. J. Appl. Phys. 36 (1997) 5436.

11. P.A.T.T. van Veenendaal, C.M.H. van der Werf, J.K. Rath, R.E.I. Schropp, J. Non-Cryst. Solids 299-302 (2002) 1184.

12. J.K. Rath, A.J. Hardeman, C.H.M. van der Werf, P.A.T.T. van Veenendaal, M.Y.S. Rusche, R.E.I. Schropp, Thin Solid Films 430 (2003) 67.

13. M. Konagai, T. Tsushima , M.K. Kim , K. Asakusa, A. Yamada, Y. Kudriavtsev, A. Villegas , R. Asomoza, Thin Solid Films 395 (2001) 152.

14. Y. Ide, Y. Saito, A. Yamada, M. Konagai, Jpn. J. Appl. Phys. 43 (2004) 2419.

15. E. Iwaniczko, Y. Xu, R.E.I. Schropp, A.H. Mahan, Thin Solid Films 430 (2003) 212.

16. K. Yamamoto, M. Yoshimi, Y. Tawada, Y. Okamoto, A. Nakajima, Sol. Energy Mater. Sol. Cells 66 (2001) 117.

17. J. Cifre, J. Bertomeu, J. Puigdollers, M.C. Polo, J. Andreu, A. Lloret, Appl. Phys. A 59 (1994) 645.

18. M. Fonrodona, D. Soler, J.M. Asensi, J. Bertomeu, J. Andreu, J. Non-Cryst. Solids 299-302 (2002) 14.

19. P. Stradins, Sol. Energy Mater. Sol. Cells 78 (2003) 349.

20. H. Keppner, J. Meier, P. Torres, D. Fischer, A. Shah, Appl. Phys. A 69 (1999) 169. 
HW3-56

21. J. Meier, E. Vallat-Sauvain, S. Dubail, U. Kroll, J. Dubail, S. Golay, L. Feitknecht, P. Torres, S. Fay, D. Fisher, A. Shah, Sol. Energy Mater. Sol. Cells 66 (2001) 73.

22. D.L. Staebler, C.R. Wronski, Appl. Phys. Lett. 31 (1977) 292.

23. J.M. Asensi, J. Merten, C. Voz, J. Andreu, J. Appl. Phys. 85 (1999) 2939.

24. K. Taretto, U. Rau, J.H. Werner, Appl. Phys. A 77 (2003) 865.

25. H. Okamoto, H. Kida, S. Nonomura, K. Fukumoto, Y. Hamakawa, J. Appl. Phys. 54 (1983) 3236.

26. J. Merten, J.M. Asensi, C. Voz, A.V. Shah, R. Platz, J. Andreu, IEEE T. Electron Dev. 45 (1998) 423.

27. C. Voz, D. Peiró, J. Bertomeu, D. Soler, M. Fonrodona, J. Andreu, Mater. Sci. Eng. B69-70 (2000) 278 . 
HW3-56

\section{List of table and figure captions}

Table 1 Simulated solar cell efficiencies as a function of mobility $(\mu)$ and $\mathrm{N}_{\mathrm{d}}$.

Fig. 1 Evolution of the efficiency of $\mu \mathrm{c}-\mathrm{Si}: \mathrm{H}$ solar cells deposited by HWCVD. Solid symbols correspond to cells having the doped layers deposited by PECVD whereas the rest are of completely Hot-Wire grown devices.

Fig. 2 Evolution of $\mu \tau_{\text {eff }}$ with AM1.5 light exposure for $\mathrm{p}-\mathrm{i}-\mathrm{n}$ solar cells deposited at $\mathrm{SC}=5.6 \%$ (squares) and $6.2 \%$ (circles). Solid circles correspond to the first light soaking period and open ones to that performed after 30 minutes of thermal annealing at $180^{\circ} \mathrm{C}$.

Fig. 3 Normalized Raman spectra of the solar cells considered and the difference between them.

Fig. 4 Fast Fourier Transform (FFT) treatment of High-Resolution TEM images at different depths of the intrinsic layer of two p-i-n solar cells with i-layers deposited at $\mathrm{SC}=5.6 \%$ and $6.2 \%$.

Fig. 5 a) J(V) characteristics of the stable solar cell under AM1.5 (100 mW/ $\left.\mathrm{cm}^{2}\right)$ illumination, b) External quantum efficiency of the same cell. 
HW3-56

Table 1

\begin{tabular}{|c|c|c|c|c|c|}
\hline $\begin{array}{c}\mathrm{N}_{\mathrm{d}} \\
\left(\mathrm{cm}^{-3}\right)\end{array}$ & $\begin{array}{c}\mu \\
\left(\mathrm{cm}^{2} / \mathrm{Vs}\right)\end{array}$ & $\begin{array}{c}\mathrm{V}_{\mathrm{oc}} \\
(\mathrm{V})\end{array}$ & $\begin{array}{c}\mathrm{J}_{\mathrm{sc}} \\
\left(\mathrm{mA} / \mathrm{cm}^{2}\right)\end{array}$ & $\mathrm{FF}$ & $\eta$ \\
\hline $10^{14}$ & 1 & 0.656 & 24.6 & 0.725 & $11.7 \%$ \\
\hline $10^{15}$ & 1 & 0.544 & 21.7 & 0.570 & $6.7 \%$ \\
\hline $10^{16}$ & 1 & 0.394 & 8.14 & 0.363 & $1.2 \%$ \\
\hline $10^{14}$ & 10 & 0.656 & 24.9 & 0.742 & $12.1 \%$ \\
\hline $10^{15}$ & 10 & 0.544 & 24.4 & 0.680 & $9.0 \%$ \\
\hline $10^{16}$ & 10 & 0.419 & 19.9 & 0.519 & $4.3 \%$ \\
\hline
\end{tabular}


HW3-56

Figure 1

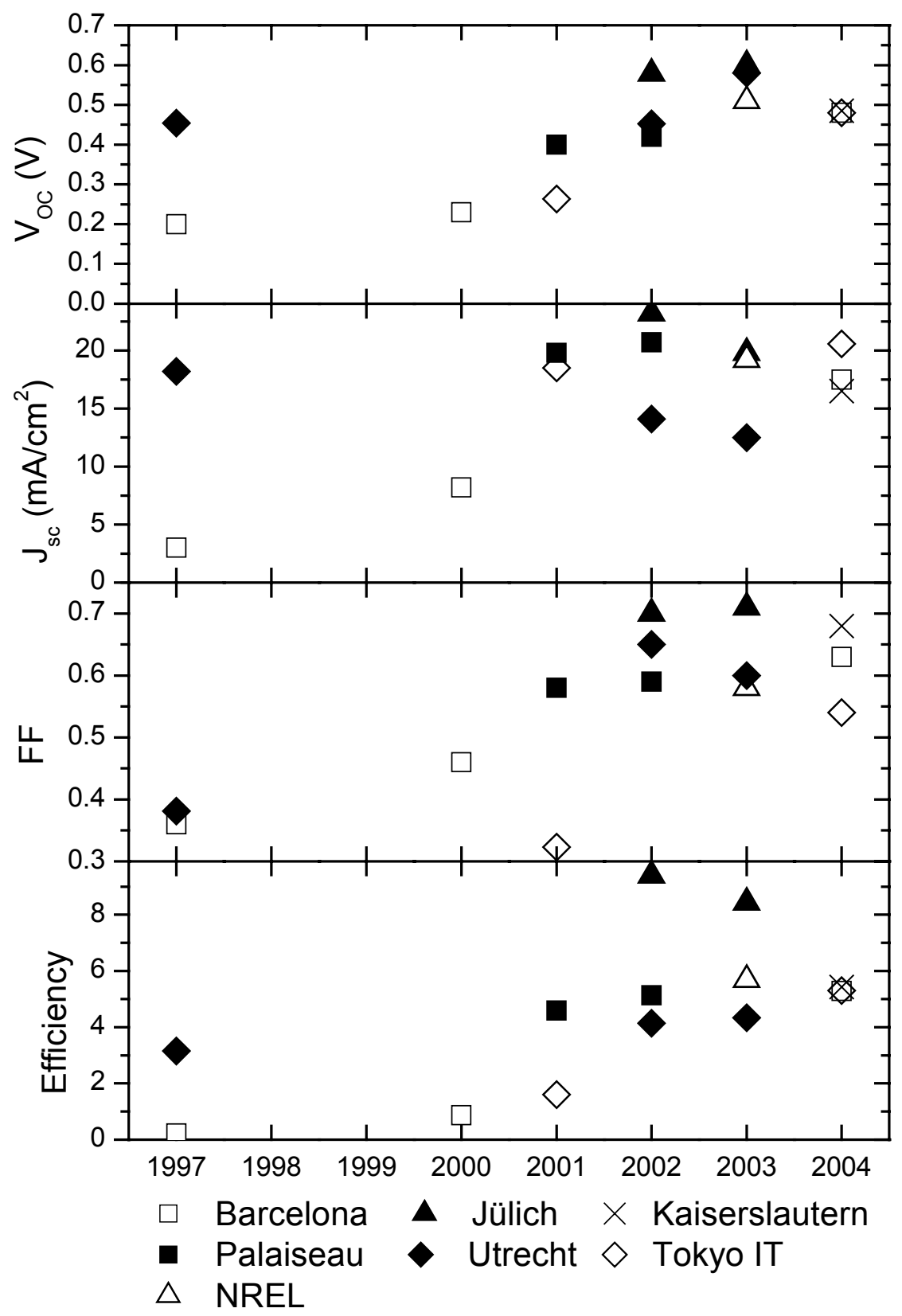


HW3-56

Figure 2

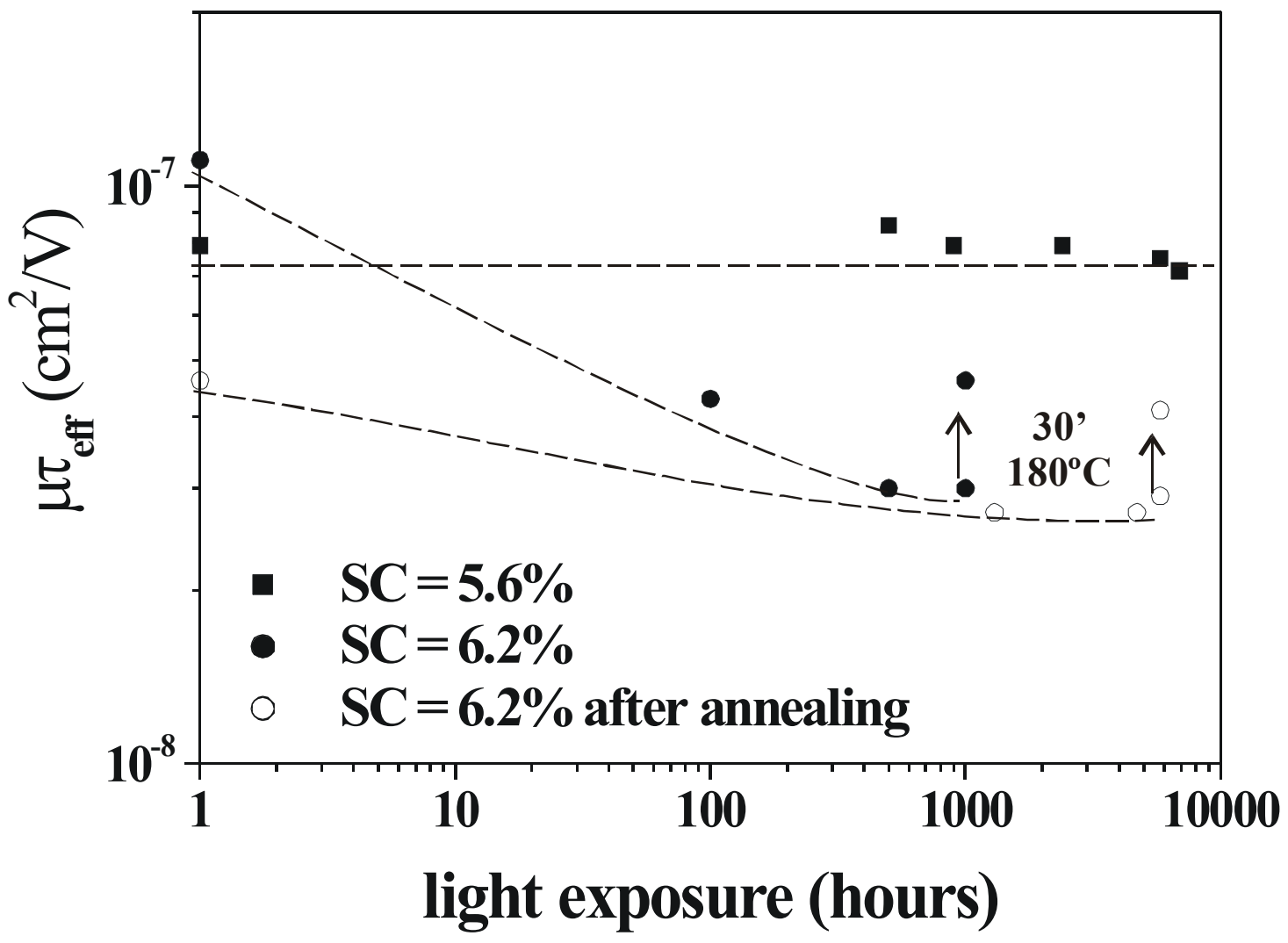


HW3-56

Figure 3

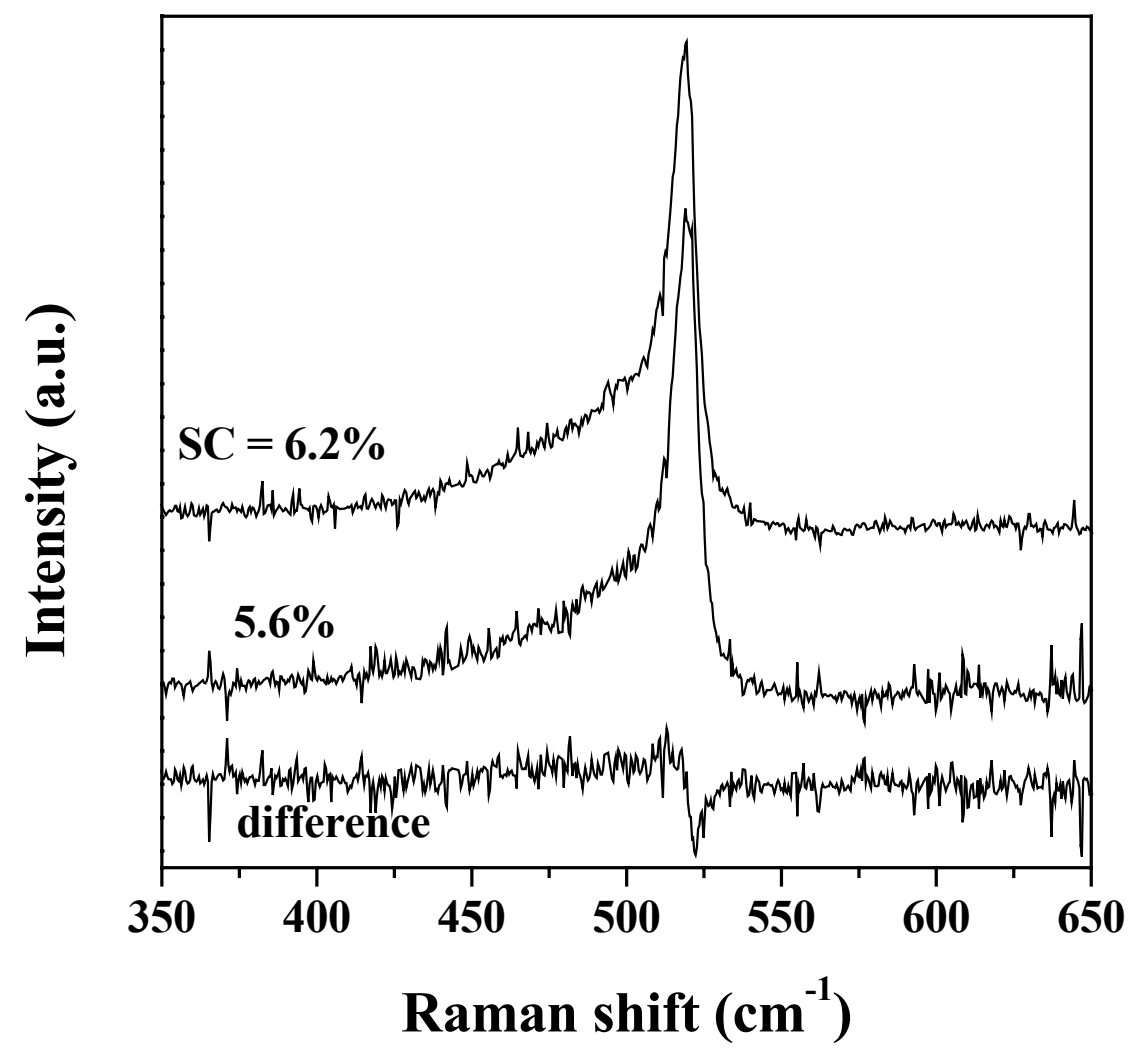


Figure 4

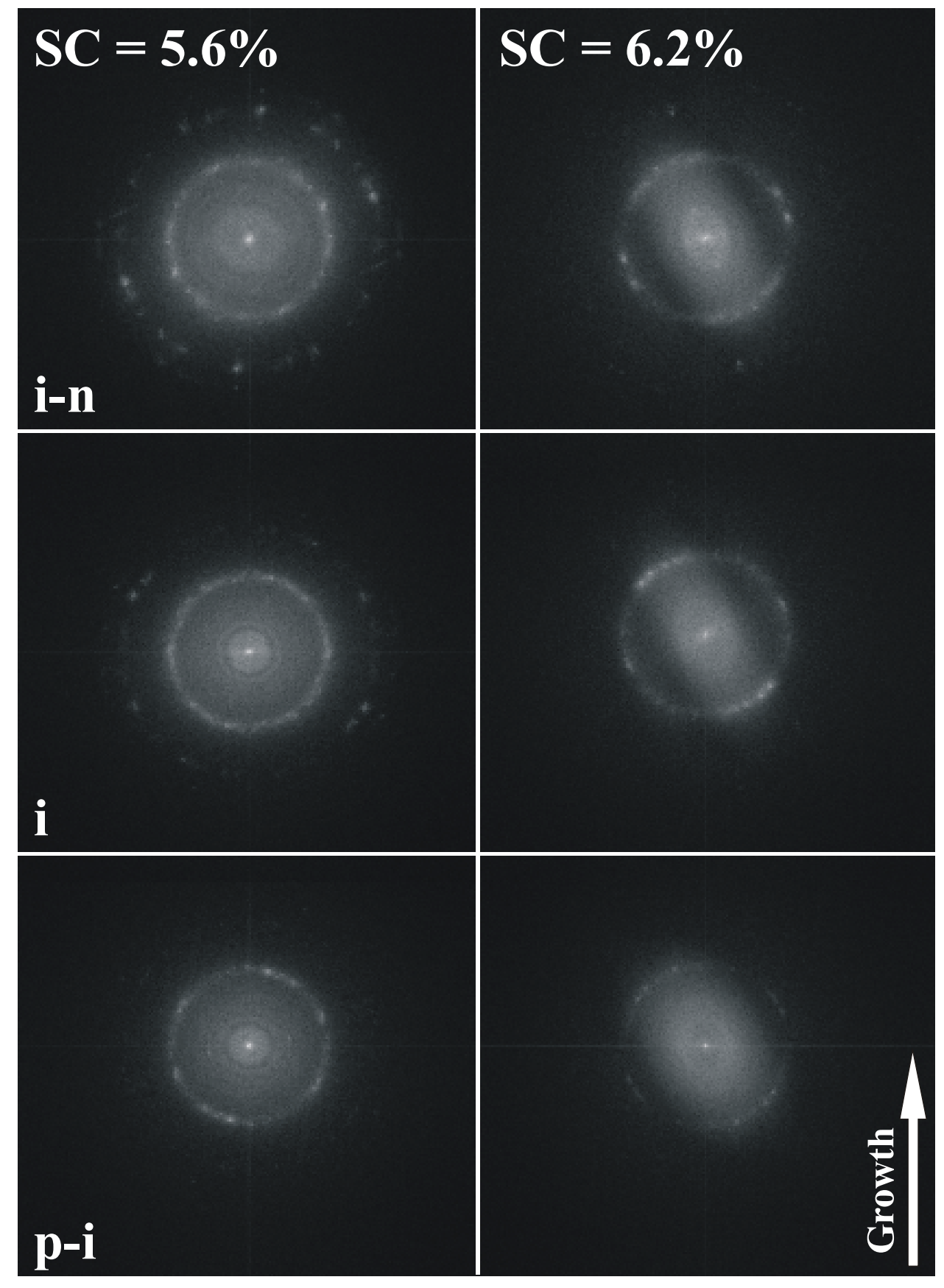


HW3-56

Figure 5a

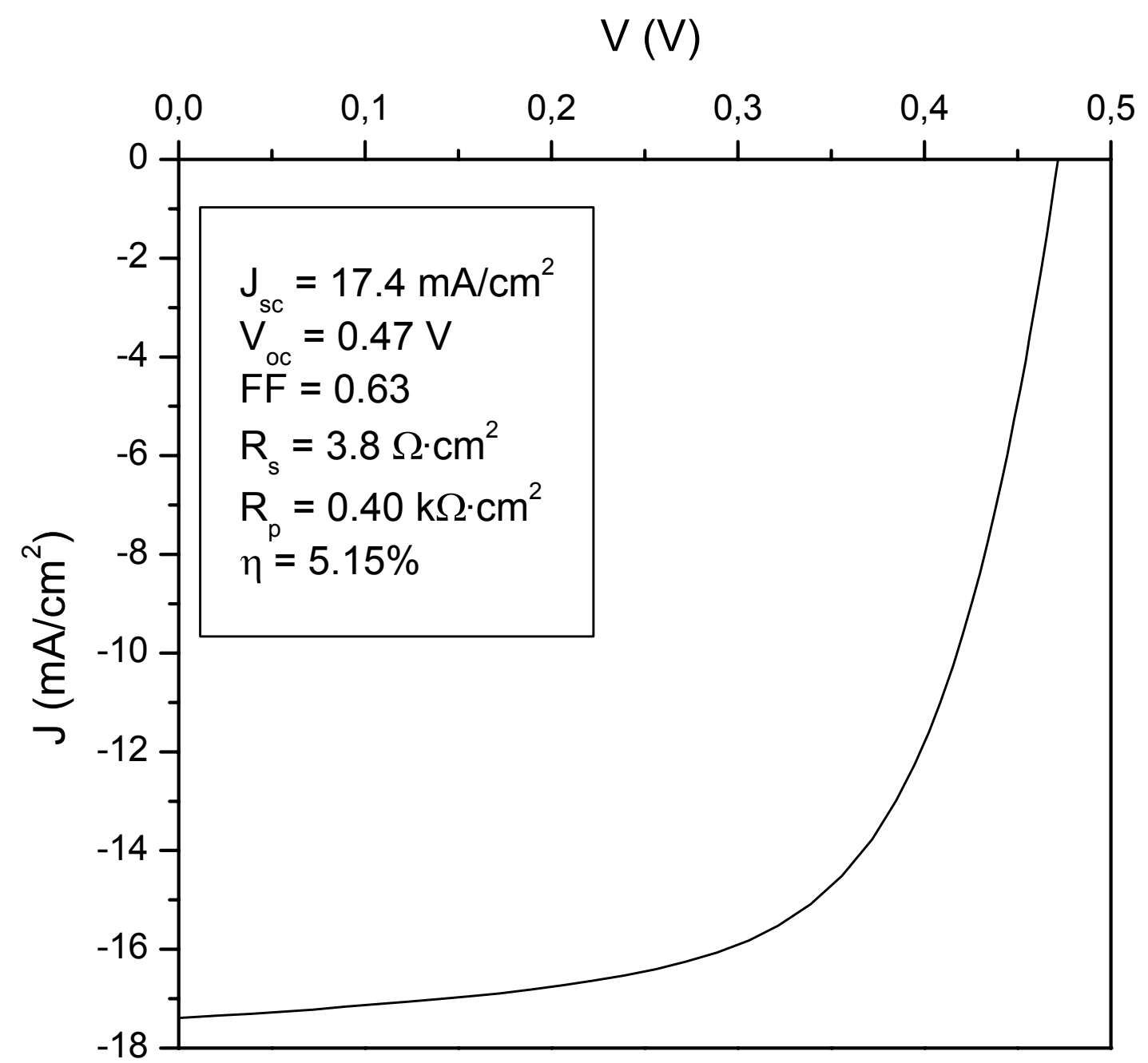


HW3-56

Figure 5b

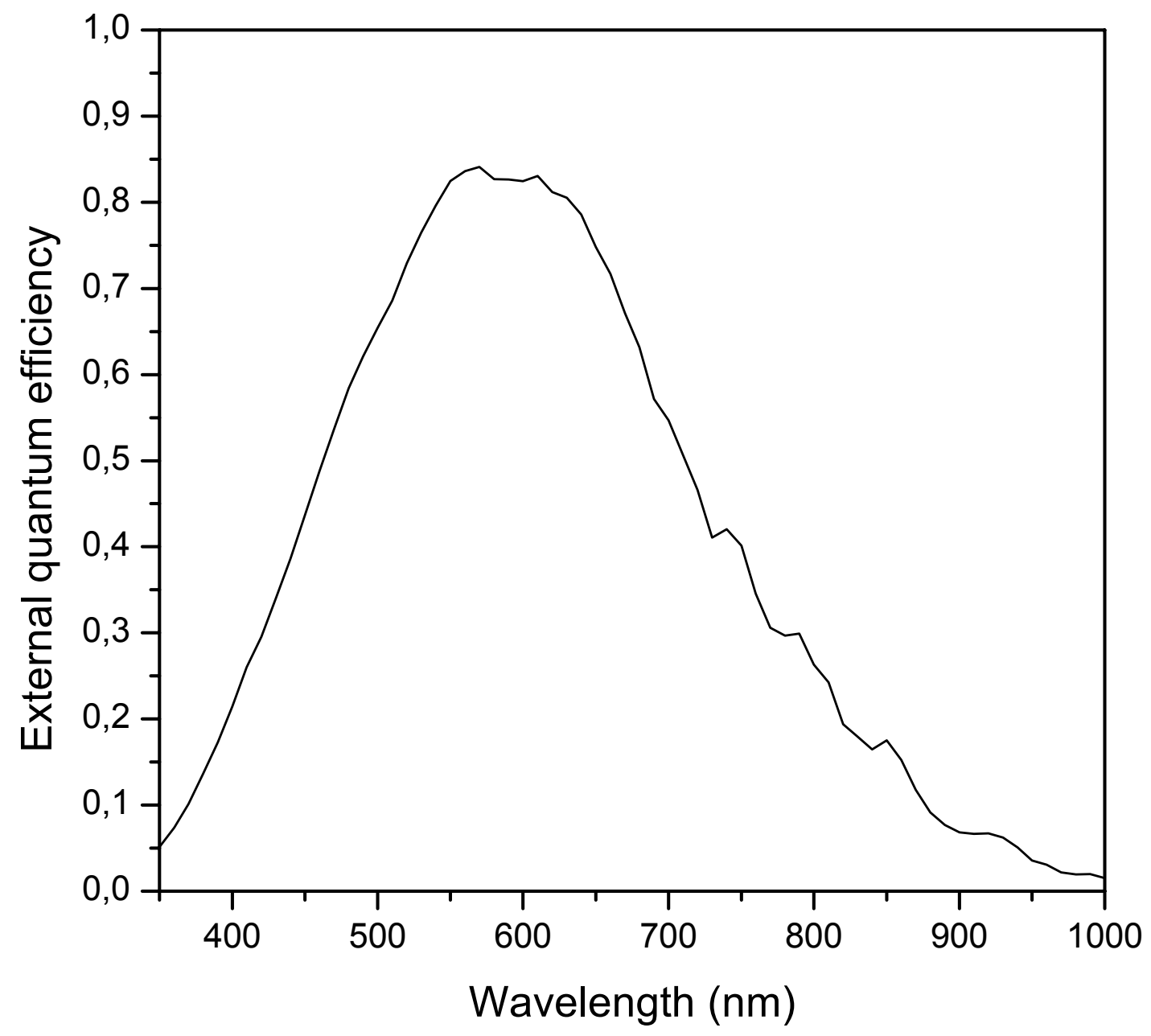

